\section{Economic Evaluation of Methyl Bromide Alternatives for the Production of Strawberries in the Southeastern United States}

\author{
Olha Sydorovych ${ }^{1}$, Charles D. Safley ${ }^{2}$, Lisa M. Ferguson ${ }^{3}$, \\ E. Barclay Poling ${ }^{4}$, Gina E. Fernandez ${ }^{5}$, Phil M. Brannen ${ }^{6}$, \\ David M. Monks ${ }^{7}$, and Frank J. Louws ${ }^{8}$
}

AdDITIONAL INDEX WORDS. cost of production, partial budget analysis, fumigation, Fragaria $\times$ ananassa

Summary. Partial budget analysis was used to evaluate soil treatment alternatives to methyl bromide (MeBr) based on their cost-effectiveness in the production of strawberries (Fragaria $\times$ ananassa). The analysis was conducted for two geographical areas: the piedmont and coastal plain area (including North Carolina and Georgia) and the mountain area of western North Carolina, based on 7 years of field test data. The fumigation alternatives evaluated were Telone-C35 (1,3dichloropropene $61.1 \%$ + chloropicrin $34.7 \%)$, Telone II (1,3-dichloropropene 94\%), chloropicrin (Chlor-o-pic 99\% and TriClor EC ), InLine (1,3-dichloropropene $\mathbf{6 0 . 8 \%}+$ chloropicrin $33.3 \%$ ), and metam sodium (Vapam or Sectagon 42 , $42 \%$ sodium methyldithiocarbamate). The $\mathrm{MeBr}$ formulation was $67 \% \mathrm{MeBr}$ and $33 \%$ chloropicrin (Terr-O-Gas) with the exception of the earlier trials where a 98:2 ratio was used. In the piedmont and coastal plain area, the soil treated with chloropicrin showed the best results with an additional return of $\$ 1670 /$ acre relative to $\mathrm{MeBr}$, followed by Telone-C35 with an additional return of \$277/ acre. The projected return associated with shank-applied metam sodium was approximately equal to the estimated return a grower would receive when applying MeBr. Fumigating with drip-applied metam sodium, InLine, and Telone II as well as the nonfumigated soil treatment resulted in projected losses of \$2182, $\$ 2233, \$ 4179$, and $\$ 6450$ per acre, respectively, relative to $\mathrm{MeBr}$. In the mountain area, all of the alternatives resulted in a projected increase in net returns relative to $\mathrm{MeBr}$. The largest projected increase was $\$ 1320 /$ acre for the InLine treatment, while the added returns for the TriClor and Telone-C35 applications were estimated to be $\$ 509$ and $\$ 339$ per acre, respectively. The drip-applied metam sodium application resulted in an additional return of $\$ 40 / \mathrm{acre}$, and the added revenue for the nonfumigated soil treatment was $\$ 24 /$ acre more than $\mathrm{MeBr}$ treatment. Although technical issues currently associated with some of the alternatives may persist, results indicate that there are economically feasible fumigation alternatives to $\mathrm{MeBr}$ in the production of strawberries in the southeastern U.S.

\footnotetext{
${ }^{1}$ Postdoctoral Associate, Department of Agricultural and Resource Economics, North Carolina State University, Raleigh, NC 27695-8109.

${ }^{2}$ Professor, Department of Agricultural and Resource Economics, North Carolina State University, Raleigh, NC 27695-8109.

${ }^{3}$ USDA-APHIS-PPQ, Center for Plant Health Science and Technology, Plant Epidemiology and Risk Analysis Laboratory, Raleigh, NC 27606; formerly Researcher/Project Coordinator, Department of Plant Pathology, North Carolina State University, Raleigh NC 27695-7616.

${ }^{4}$ Professor, Department of Horticultural Science, North Carolina State University, Raleigh NC 27695-7609. ${ }^{5}$ Associate Professor, Department of Horticultural Science, North Carolina State University, Raleigh NC 27695-7609

${ }^{6}$ Extension Plant Pathologist, Department of Plant Pathology, University of Georgia, Athens, GA 30602-7274. ${ }^{7}$ Professor, Department of Horticultural Science, North Carolina State University, Raleigh NC 27695-7609. ${ }^{8}$ Associate Professor, Department of Plant Pathology, North Carolina State University, Raleigh NC 27695-7616. Mention of a trademark, proprietary product, or vendor does not constitute a guarantee or warranty of the product and does not imply its approval to the exclusion of other products or vendors that also may be suitable.

We thank Jim Driver, Nastacia Heiniger, Melanie Halsey, Rocco Schiavonne, and others for assistance with data collection. We appreciate the financial assistance of The North Carolina Strawberry Growers Association and support through the competitive grants program of USDA CSREES \#00-51102-9570 and 2002-51102-01926. Corresponding authors: Charles_Safely@ncsu.edu (economics) or Frank_Louws@ncsu.edu (production).
}

$\mathrm{M}$ ethyl bromide $(\mathrm{MeBr})$ is a highly effective broadspectrum fumigant used to control insects, nematodes, weeds, and pathogens (Gullino et al., 2003; Martin, 2003; Ristaino and Thomas, 1997; Schneider et al., 2003). The United States uses about 38 million $\mathrm{lb}$ of $\mathrm{MeBr}$ (a.i.) each year for preplant soil fumigation, accounting for $70 \%$ to $75 \%$ of the total use [Osteen, 2000; Ristaino and Thomas, 1997; U.S. Department of Agriculture (USDA), 2005a]. Under the Montreal Protocol of 1991, MeBr was defined as a chemical that contributes to the depletion of the stratospheric ozone layer and a phase-out schedule was implemented with a targeted phase-out in 2005 [USDA, 2005a; U.S. Environmental Protection Agency (EPA), 2004]. As a result of the obligations imposed under the Montreal Protocol, importation and production of $\mathrm{MeBr}$ ceased in the U.S. beginning 1 Jan. 2005, except for emergency and critical use exemptions (EPA, 2004).

The phase-out of $\mathrm{MeBr}$ as a preplant soil fumigant may result in considerable financial losses for the U.S. farmers (Carpenter et al., 2000; Carter et al., 2005; Osteen, 2000; USDA, $2005 \mathrm{~b})$. There is no known single alternative fumigant, chemical, or other technology that can readily substitute for $\mathrm{MeBr}$ in efficacy, low cost, ease of use, availability, worker safety, and environmental safety below the ozone layer (USDA, 2005b). Possible alternatives include host plant resistance, biological control, different cultural practices, and alternative chemicals, either alone or in combination (Gullino et al., 2003; Manning and Fennimore, 2001; Martin, 2003; Rieger et al., 2001; Ristaino and Thomas, 1997; Schneider et al., 2003 ). The availability of the alternative control measures will generally be limited to a specific crop or use because specific crops have widely varying requirements associated with variations in the target pests, soil types, climates,

\begin{tabular}{|c|c|c|c|}
\hline \multicolumn{4}{|l|}{ Units } \\
\hline $\begin{array}{l}\text { To convert } \\
\text { U.S. to SI, } \\
\text { multiply by }\end{array}$ & U.S. unit & SI unit & $\begin{array}{l}\text { To convert } \\
\text { SI to U.S., } \\
\text { multiply by }\end{array}$ \\
\hline 0.4047 & $\operatorname{acre}(\mathrm{s})$ & ha & 2.4711 \\
\hline 9.3540 & $\mathrm{gal} / \mathrm{acre}$ & $\mathrm{L} \cdot \mathrm{ha}^{-1}$ & 0.1069 \\
\hline 2.5400 & inch(es) & $\mathrm{cm}$ & 0.3937 \\
\hline 0.4536 & $\mathrm{lb}$ & $\mathrm{kg}$ & 2.2046 \\
\hline 1.1209 & $\mathrm{lb} / \mathrm{acre}$ & $\mathrm{kg} \cdot \mathrm{ha}^{-1}$ & 0.8922 \\
\hline 0.9464 & $\mathrm{qt}^{\prime}$ & $\mathrm{L}$ & 1.0567 \\
\hline
\end{tabular}

Hortlechnology · January-March 2006 16(1) 
and state and local regulations (USDA, 2005a). Chemical alternatives studied most intensively include products that have a long history of use such as 1,3-dichloropropene, metam sodium, chloropicrin and combinations of these [e.g., 61.1\% 1,3-dichloropropene + $34.7 \%$ chloropicrin or Telone-C35 (Dow AgroSciences, Indianapolis] (Duniway, 2002; Martin, 2003; Schneider et al., 2003).

Nearly $80 \%$ of preplant $\mathrm{MeBr}$ soil fumigation is used for strawberries, tomatoes (Lycopersicon esculentum), ornamentals and nursery crops, and peppers (Capsicumannuum) (USDA, 2005a). Therefore, strawberry growers present one of the major impact groups for the new $\mathrm{MeBr}$ regulations. For example, in the southeastern U.S. (Georgia, North Carolina, South Carolina, Tennessee, and Virginia), based on an economic impact analysis (Carpenter et al., 2000; Norman, 2005; Osteen, 2000; USDA, 2001) the revenue of small to mid-sized farms is expected to decrease due to the phase-out of $\mathrm{MeBr}$ if suitable replacements are not found.

Excluding Florida, which has large commercial operations, the strawberry industry in the southeastern U.S. is comprised primarily of small to midsized family farms (Safley et al., 2004). Therefore the focus of this research effort was on the production and direct marketing of strawberries and not the larger operations in Florida that utilize commercial distribution channels. The majority of the industry employs an annual plasticulture system that is dependent on $\mathrm{MeBr}$ as a soil fumigant. Fields are prepared in the early fall (September). Raised beds are formed 6 to 8 inches high, a single drip tape line is laid within the bed, the soil within the bed is fumigated, and the bed is covered with black polyethylene. Within 2 to 4 weeks strawberry transplants are field set, depending on the required plant-back interval for the individual fumigant, as double rows on each bed. Harvest commences in spring (April) for 6 to 8 weeks; and after the crop is destroyed in June, rotation crops are grown or the land is prepared for the next strawberry crop. In addition to significant weather-related problems that strawberry plasticulture in the southeastern U.S. can often encounter (e.g., frosts, freezes, hail, excess rain, tropical storms, and/or hurricanes), other deterrents to optimal production include weed pressure and the black root rot complex caused primarily by the root rot pathogens belonging to the genera Rbizoctonia and Pythium (Abad et al., 1999, 2002; Ferguson et al., 2003).

A series of $\mathrm{MeBr}$ alternative trials were conducted in multiple sites in North Carolina and southern Georgia (Brannen and Louws, 2002; Brannen et al., 2003; Driver et al., 2001; Ferguson et al., 2001, 2002, 2003; Fernandez et al., 2000; Louws et al., 1998a, 1998b, 2000), and have documented the technical feasibility or limitations of alternative fumigants in the annual strawberry production system. The purpose of this report was to analyze the economic feasibility of the chemical alternatives to $\mathrm{MeBr}$ that can be substituted in the production of strawberries. The specific objectives were to:

1) Estimate the costs and returns associated with growing, harvesting, and marketing strawberries when applying the preplant fumigation with $\mathrm{MeBr}$ using the plasticulture production system, and

2) Evaluate the chemical alternatives to $\mathrm{MeBr}$ currently available to strawberry growers based on the impact on net returns.

\section{Methodology and assumptions}

It was initially assumed that the success of a specific alternative fumigant would vary throughout the climactic regions in the southeastern U.S. Therefore, a series of trials were conducted in the coastal plain and piedmont regions of North Carolina and Georgia, and the mountain region of North Carolina. As expected, the average yields and pest pressures varied across these sites, affecting the outcomes of alternative soil treatments (Brannen and Louws, 2002; Brannen et al., 2003; Driver et al., 2001; Ferguson et al., 2001, 2002, 2003; Fernandez et al., 2000; Louws et al., 1998a, 1998b, 2000). Consequently, the economic evaluation was conducted for two separate geographic areas for which it was possible to assume uniform strawberry-growing conditions. The first area combines the piedmont and coastal plain regions of North Carolina and Georgia, while the second area represents the mountain region of western North Carolina. Experimental plots in Plymouth, Clayton, and Bunn, N.C.; and Vidalia, Ga., represented the piedmont and coastal plain area, and trial plots in Fletcher and Leicester, N.C., represented the mountain area. The piedmont and coastal plain region of North Carolina and Georgia will be referred to as the piedmont and coastal plain area hereafter.

To accomplish the objectives of this study, a cost model for a plasticulture production system was first developed for a 5-acre strawberry planting using $\mathrm{MeBr}$ as the standard fumigation treatment (Safley et al., 2004). Production practices were based on customary management practices recommended by North Carolina State University extension and research horticultural specialists, and practiced by growers. Whereas the original cost model presented in Safley et al. (2004) synthesized the production practices and yields for the entire state of North Carolina, the base budgets for this study were adjusted to reflect the production techniques and average annual yields for the areas discussed above.

It was assumed that machinery and equipment were purchased new at 2001 purchase prices. The machinery and equipment used in this budget reflect machinery components that can be used for other farming enterprises in addition to growing strawberries on a typical diversified farm. Therefore, the total machinery expense was adjusted to reflect the portion of costs attributable to strawberry production enterprise based on assumptions about typical use of the machinery on an average farm. The fumigation and irrigation equipment were the exceptions because they were used solely for strawberry production. The overhead irrigation system was used primarily for frost and freeze protection. The drip irrigation system was used for managing soil moisture and fertilizer applications in the strawberry field.

Input prices were obtained from local dealers who regularly supply strawberry growers. Because land rental rates vary throughout the southeastern U.S., a land charge was not included in the budget. Hired employees were paid $\$ 8.25 / \mathrm{h}$ while the owner/operator was compensated at a rate of $\$ 16.39 / \mathrm{h}$. These labor rates include workers' compensation, unemployment, FICA taxes, and other overhead expenses as well as the base wage rate, and were meant to be representative of the "true" costs of labor and not just the base wage rate. 
The harvest season was assumed to last 6 weeks starting in the third week of April and continuing through May. The marketing process obviously bears a cost and varies considerably depending on the marketing system the producers use. In this study, it was assumed that all of the fruit would be sold at the farm with two-thirds of the strawberries sold through the pick-your-own (PYO) operation, and one-third sold at the fruit stand (Safley et al., 2004). A labor charge of $\$ 1.15$ per 4-qt basket was added to the cost of the prepick strawberries, while supervision labor was compensated at a rate of $\$ 8.25 / \mathrm{h}$. Supervision tasks included overseeing the pickers and checkout operations, as well as the general management of the direct market operations. It was assumed that growers received $\$ 1.40 / \mathrm{lb}$ for prepicked strawberries and $\$ 0.90 / \mathrm{lb}$ for PYO strawberries.

Fumigation treatments varied with respect to the number of years of data and the locations of the study plots (Table 1). The soil treatment alternatives evaluated in this study were
Telone-C35 (1,3-dichloropropene $61.1 \%$ + chloropicrin $34.7 \%$ ), Telone II (1,3-dichloropropene 94\%; Dow AgroSciences), chloropicrin (Chloro-pic 99\% and TriClor EC; Hendrix and Dial, Greensboro, N.C.), InLine (1,3-dichloropropene $60.8 \%+$ chloropicrin 33.3\%; Dow AgroSciences), and metam sodium [Vapam (Amvac, Newport Beach, Calif.) or Sectagon $42,42 \%$ sodium methyldithiocarbamate (Tessenderlo Kerely Inc., Phoenix)]. The $\mathrm{MeBr}$ formulation was $67 \% \mathrm{MeBr}$ and $33 \%$ chloropicrin (Terr-O-Gas; Great Lakes Chemical Corp., West Lafayette, Ind.). In addition, a nonfumigated alternative was evaluated to determine the economic necessity of fumigation in each region. Even though field studies were also conducted for iodomethane (Midas; Arvesta, San Francisco) and a combination of iodomethane and chloropicrin, these alternatives were not included in the economic analysis because of the lack of the product cost information for iodomethane.

$\mathrm{MeBr}$ (combined with chloropicrin) fumigation was considered the standard for strawberry production practice on which the base budget was built. To compare yield data between years and across sites, all yield data were normalized to the average strawberry yield for the $\mathrm{MeBr}$ plots that were obtained in the same experiment in the same year. For example, if the $\mathrm{MeBr}$ yield in experiment 1 , year 1 , site 1 was $20,000 \mathrm{lb} /$ acre, this was considered $100 \%$ yield. If alternative fumigant "A" had a yield of 23,000 lb/acre in the same experiment, this yield was considered $115 \%$. In year 2 , if the yield for $\mathrm{MeBr}$ was $25,000 \mathrm{lb} /$ acre $(100 \%)$ and the yield for alternative " $A$ " was $20,000 \mathrm{lb} /$ acre, this was considered an $80 \%$ yield. The yields for $\mathrm{MeBr}$ were averaged across all years and all sites (e.g., $22,500 \mathrm{lb} /$ acre), and the average relative yield for the alternative was calculated (e.g., 97.5\%). Then, the overall average relative yield for alternative " $\mathrm{A}$ " would be the product of the average $\mathrm{MeBr}$ yield and the average relative yield of the alternative (e.g., 22,500 $\mathrm{lb} /$ acre $\times 97.5 \%=21,938 \mathrm{lb} /$ acre $)$. This approach circumvented yield variations due to year and site effects

Table 1. Alternative soil treatments, application rates, experimental sites, and the number of sequential years the soil treatment was evaluated in strawberry production systems at each experimental site from 1996 to 2002.

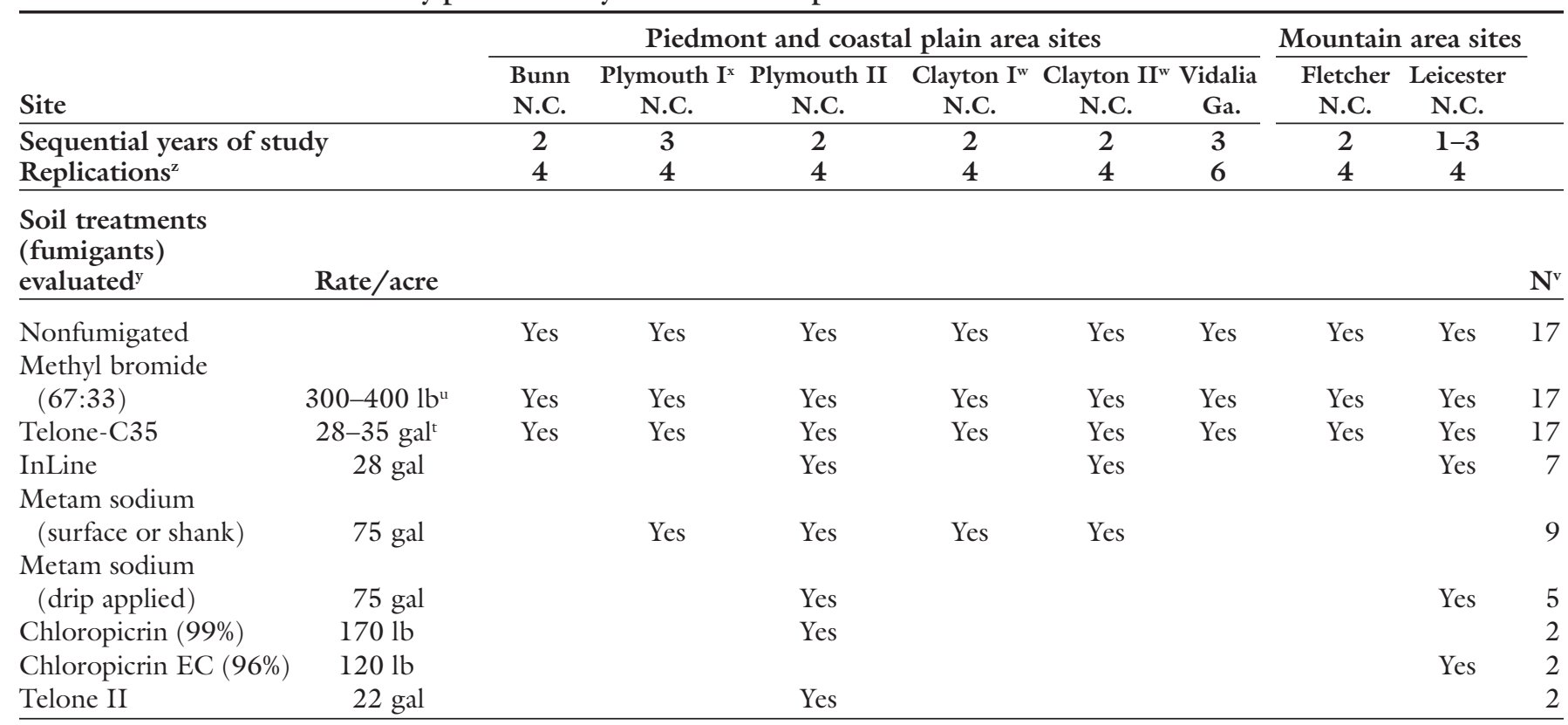

${ }^{2}$ All experiments were arranged as a randomized complete-block design with four or six replications.

${ }^{y}$ Methyl bromide $[\mathrm{MeBr}$ (67\% MeBr and 33\% chloropicrin)], Terr-O-Gas (Great Lakes Chemical Corp. West Lafayette, Ind.), Telone-C35 [61.1\% 1,3-dichloropropene + $34.7 \%$ chloropicrin (Dow AgroSciences, Indianapolis, Ind)], and chloropicrin (Chlor-o-pic 99; Hendrix and Dial, Greensboro, N.C.) were shank-injected into raised beds 24-30 inches $(61.0-76.2 \mathrm{~cm}$ ) wide and covered with black polyethylene. Metam sodium [Vapam (Amvac, Newport Beach, Calif.) or Sectagon 42 (42\% sodium methyldithiocarbamate; Tessenderlo Kerley Inc., Phoenix)] was surface applied or shank applied using five shanks on 6 -inch (15.2 $\mathrm{cm}) \mathrm{centers}$ on or into preformed raised beds and the beds were immediately rototilled (for effective distribution of the product throughout the bed profile) and covered with black polyethylene. InLine ( 1,3 -dichloropropene $60.8 \%$ + chloropicrin 33.3\%; Dow AgroSciences), metam sodium (Vapam; Amvac), and chloropicrin EC (TriClor EC; Hendrix and Dial) were applied through two drip tapes spaced at one-third and two-thirds of the bed width and after the beds had been formed and covered with black polvethylene.

xThe $\mathrm{MeBr}$ formulation used was $98: 2$ (98\% $\mathrm{MeBr}$ and $2 \%$ chloropicrin) and not 67:33 (67\% MeBr and 33\% chloropicrin).

whe metam sodium formulation used in these trials was Sectagon 42, not Vapam.

Number of observations ( $\mathrm{n}=$ number of years $\times$ number of sites per year) this treatment was tested from 1996-2002.

ul $\mathrm{lb} /$ acre $=1.1209 \mathrm{~kg} \cdot \mathrm{ha}^{-1}$

${ }^{\mathrm{t}} \mathrm{l} \mathrm{gal} / \mathrm{acre}=9.3540 \mathrm{~L} \cdot \mathrm{ha}^{-1}$ 
and normalized all yield data relative to the $\mathrm{MeBr}$ treatment.

Partial budget analysis was used to evaluate the alternative soil treatments. Partial budget analysis is a standard technique to assess the economics of a change in a farm enterprise (Kay and Edwards, 1994) and is frequently used to estimate the impact of a variety of alternative production techniques when the change involves only part of the production system (Roberts and Swinton, 1996; Warmann, 1995; Wossink and Osmond, 2002).

The partial budget technique compares the negative effects of applying a new treatment relative to a base or standard treatment to the positive effects associated with the new treatment relative to the base or standard treatment. Therefore, it requires the consideration of both the returns of treatments and changes in the structure of the production costs. Aspects of costs and returns that do not change with the treatment relative to the base are not considered in this type of analysis. The typical partial budget analysis follows a seven-point format (Dalsted and Gutierrez, 1992), which includes:

A. Negative effects:

- Added costs attributable to the new fumigant $\$$

- Reduced returns attributable to the new fumigant $\$$

- Total negative effects attributable to the new fumigant $\$$

B. Positive effects:

- Reduced costs attributable to the new fumigant $\$$

- Added returns attributable to the new fumigant $\$$

- Total positive effects attributable to the new fumigant $\$$

C. Total effects (additional/reduced revenue)

$\$$

\section{Results}

The estimated costs per acre needed to produce, harvest, and market strawberries in the piedmont and coastal plain area using $\mathrm{MeBr}$ as the fumigant are listed in Table 2. The total harvest, marketing, and production costs were estimated to be $\$ 13,556 /$ acre. Expenses were separated into six production phases: 1) land preparation, 2) preplant operations, 3) transplant and postplant operations, 4) dormant period, 5 ) preharvest, and 6) harvest and postharvest operations. Preplant operations were the most expensive set of procedures, costing an estimated $\$ 4399 /$ acre, while harvest and postharvest operations were the second most expensive phase, costing $\$ 3528$ /acre. Preharvest operations were $\$ 2138 /$ acre and transplant and postplant operations totaled \$2035/ acre. Overall materials accounted for $\$ 6470 /$ acre, labor costs made up $\$ 5359 /$ acre, and the costs linked to owning and operating the equipment totaled \$1727/acre.

The estimated fumigation costs varied with the soil treatment (Table 3 ). The projected fumigation costs associated with $\mathrm{MeBr}$ were the highest (\$1267/acre). In comparison, it cost $\$ 1196 /$ acre to fumigate with metam sodium (shank), \$1 175/acre for chloropicrin, \$1 107/acre for Telone-C35, \$1066/acre for TriClor, \$1059/acre for InLine, \$988/acre for Telone II, and $\$ 904 /$ acre for metam sodium (drip). The nonfumigated alternative was the least expensive soil treatment option with a cost estimate of \$767/ acre, which included the estimates of equipment, material, and labor costs associated with laying the drip tape and plastic mulch. The estimated reduced fumigation costs per acre for each alternative relative to $\mathrm{MeBr}$ are listed in the last column of the table. The cost reduction ranged from a low of $\$ 71.03 /$ acre for metam sodium (shank) to a high of $\$ 363.18 /$ acre for metam sodium (drip). The nonfumigated treatment was $\$ 500 /$ acre lower than the cost of fumigating with $\mathrm{MeBr}$.

The estimated differences in the weed pressure were obtained from the Plymouth experiments, and were assumed to hold constant for other locations. The predominant weeds at Plymouth were henbit (Lamium amplex), vetch (Vicia spp.), chickweed (Stellaria media), white clover (Trifolium repens), and cudweed (Gnaphaliumspp.). Lesser weed species included grasses (Lolium spp. and Poa spp.), spepardspurse (Capsella bursapatoris), wild carrot (Daucus carota) carolina geranium (Geranium carolinianum), curly dock (Rumex crispus), broadleaf dock (Rumex obtusifolius), and corn spurry (Spergula arvensis). Weed pressure fell into three groups (Table 4). Not surprisingly, the nonfumigated treatment resulted in the highest number of planting holes per acre with weeds, while chloropicrin had the second highest number of holes with weeds. The remaining fumigants had relatively similar levels of weed infestation. The differences in weed pressure resulted in corresponding differences in the costs of weeding associated with each treatment. Weeding costs were calculated assuming that it took an average of $11 \mathrm{~s}$ per hole to remove the weeds. This time estimate was based on random samples taken throughout the experiments. The cost of weeding for the nonfumigated treatment was $\$ 524 /$ acre and the weeding cost for chloropicrin was $\$ 224$ /acre. The weeding costs for the remaining soil treatments ranged from $\$ 145$ /acre for metam sodium (drip) to \$104/acre for metham sodium (shank). The additional costs of weeding relative to the $\mathrm{MeBr}$ treatment are also presented in the last column of Table 4 . The nonfumigated soil treatment had the highest increase in the weeding cost relative to $\mathrm{MeBr}, \$ 398 /$ acre and the chloropicrin soil treatment required an additional $\$ 97 /$ acre.

While strawberry production practices for the mountain area were assumed to be identical to those in the piedmont and coastal plain area, the projected annual yields were considerably lower. Based on 5 years of data, the projected strawberry yield associated with the $\mathrm{MeBr}$ soil treatment in the piedmont and coastal plain area was $26,673 \mathrm{lb} /$ acre, compared to $11,101 \mathrm{lb} /$ acre in the mountain area (Tables 5 and 6). Therefore, the harvest costs per acre were adjusted to account for the lower labor expenses and harvest-related materials in the mountain area.

The chloropicrin soil treatment had the highest projected yield in the piedmont and coastal plain area $(28,377 \mathrm{lb} /$ acre) (Table 5). Fumigating with Telone-C35, MeBr, and shank-applied metam sodium resulted in similar yields of $26,806 \mathrm{lb} / \mathrm{acre}$, $26,673 \mathrm{lb} /$ acre, and 26,604 lb/acre, respectively. Yields for the InLine and drip-applied metam sodium application were 24,193 lb/acre and 24,103 $\mathrm{lb} / \mathrm{acre}$, while Telone II and the nonfumigated treatments had the lowest yields of 22,253 lb/acre and 20,010 $\mathrm{lb} / \mathrm{acre}$, respectively. Projected total harvest costs, including harvest materials and labor, and projected yield values associated with estimated yield levels for each alternative are presented in the table as well.

Strawberry yields were gener- 
Table 2. Estimated costs per acre needed to produce, harvest, and market strawberries in the piedmont and coastal plain areas of North Carolina and Georgia using the plasticulture production system and fumigating with methyl bromide (MeBr).

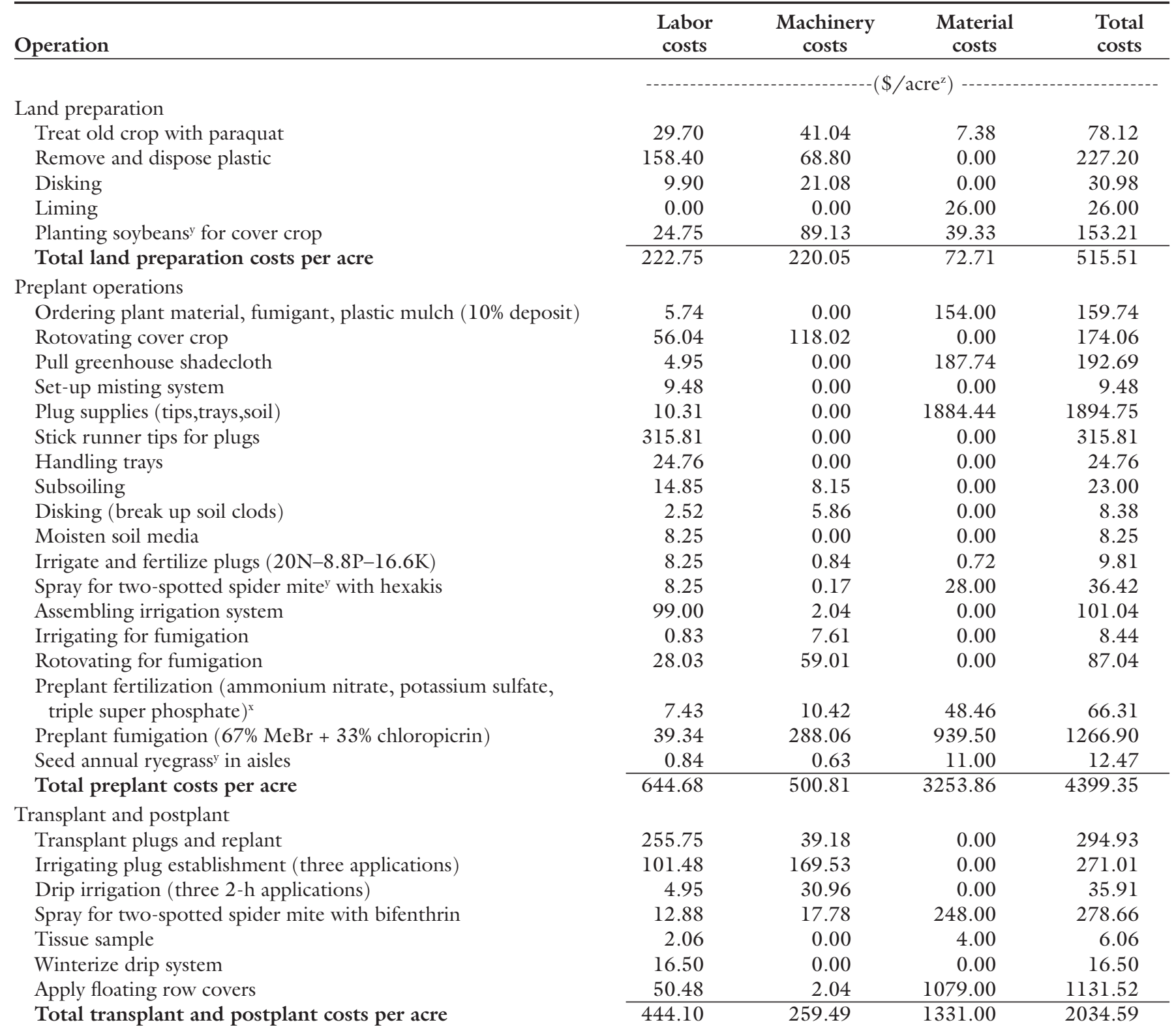

Table 2 continued on next page.

ally much lower in the mountain area (Table 6). The highest yield was $12,235 \mathrm{lb} /$ acre associated with the InLine treatment, followed by TriClor (11,497 lb/acre), Telone-C35 (11,297 $\mathrm{lb} /$ acre $), \operatorname{MeBr}(11,101 \mathrm{lb} /$ acre $)$, and the nonfumigated alternative $(11,021$ lb/acre). Fumigating with the dripapplied metam sodium produced the lowest yield (10,791 lb/acre). Similarly to the previous table, projected total harvest costs, harvest costs relative to $\mathrm{MeBr}$, projected yield values, and yield values relative to $\mathrm{MeBr}$ associated with estimated yield levels for each alternative are also presented.
The positive and negative effects for each soil treatment are shown in Tables 7 and 8 . The costs were calculated using the projected fumigation, weeding, and harvest costs associated with the alternative soil treatments presented in Tables 2 through 6. The returns were based on the projected yield values of the alternative soil treatments presented in Tables 5 and 6. In this analysis it was assumed that added (reduced) costs for the alternative treatments were incurred if one or more of the following conditions were true.

- The alternative treatment had higher (lower) fumigation costs, including material, equipment, and labor costs.

- The alternative treatment resulted in higher (lower) yield, and therefore, higher (lower) yield-related labor and material costs.

- The alternative treatment was associated with higher (lower) weed pressure, and therefore, higher (lower) hand weeding costs.

Since MeBr was the standard or base treatment, there were no added costs or reduced returns for this fumigant, and the total effects are zero. The results of the partial budget analysis 
Table 2. Continued from previous page.

\begin{tabular}{|c|c|c|c|c|}
\hline Operation & $\begin{array}{l}\text { Labor } \\
\text { costs }\end{array}$ & $\begin{array}{c}\text { Machinery } \\
\text { costs }\end{array}$ & $\begin{array}{c}\text { Material } \\
\text { costs }\end{array}$ & $\begin{array}{l}\text { Total } \\
\text { costs }\end{array}$ \\
\hline Internet and weather service (annual fee) & 0.00 & 0.00 & 83.88 & 83.88 \\
\hline Remove and reapply row covers & 297.00 & 0.00 & 0.00 & 297.00 \\
\hline White-tail deer ${ }^{y}$ control & 24.75 & 0.00 & 96.25 & 121.00 \\
\hline Remove row cover and dead foliage & 379.50 & 0.00 & 0.00 & 379.50 \\
\hline Dormant spray (captan) & 6.44 & 8.89 & 14.00 & 29.33 \\
\hline Scout for two-spotted spider mite & 16.39 & 0.00 & 0.00 & 16.39 \\
\hline Total dormant costs per acre & 736.38 & 8.89 & 194.13 & 939.40 \\
\hline \multicolumn{5}{|l|}{ Preharvest } \\
\hline Pull plants through plastic & 103.10 & 0.00 & 0.00 & 103.10 \\
\hline \multicolumn{5}{|l|}{ Spray for two-spotted spider mite with bifenthrin (two } \\
\hline applications) & 12.88 & 17.78 & 248.00 & 278.66 \\
\hline Connect drip system & 49.50 & 0.00 & 0.00 & 49.50 \\
\hline Check overhead irrigation system & 8.20 & 0.00 & 0.00 & 8.20 \\
\hline Inject mefenoxam (two applications) & 32.78 & 27.36 & 210.00 & 270.14 \\
\hline Spray for clipper weevil with chlorpyrifos & 6.44 & 8.89 & 11.60 & 26.93 \\
\hline Tissue sample (three samples) & 6.18 & 0.00 & 12.00 & 18.18 \\
\hline Inject fertilizer (Sul-Po-Mg, boron, liquid nitrogen $)^{x}$ & 16.39 & 13.68 & 2.95 & 33.02 \\
\hline Reapply row covers for freeze & 198.00 & 0.00 & 0.00 & 198.00 \\
\hline Freeze protection-overhead irrigation (four applications) & 52.44 & 399.98 & 0.00 & 452.42 \\
\hline Botrytis fruit $\operatorname{rot}^{\mathrm{w}}$ control with captan & 6.44 & 9.71 & 14.00 & 30.15 \\
\hline Polination with honeybees ${ }^{y}$ & 0.00 & 0.00 & 70.00 & 70.00 \\
\hline Total preharvest costs per acre & 759.14 & 555.64 & 823.67 & 2138.45 \\
\hline Total production costs per acre & & & & $10,027.30$ \\
\hline \multicolumn{5}{|l|}{ Harvest and postharvest operations } \\
\hline Picking supervision and fruit stand baskets & 693.00 & 0.00 & 0.00 & 693.00 \\
\hline Prepick harvest expense & 1704.30 & 0.00 & 518.70 & 2223.00 \\
\hline Drip irrigation $($ six applications $=18 \mathrm{~h})$ & 19.68 & 92.88 & 0.00 & 112.56 \\
\hline Spray for two-spotted spider mite with abamectin & 6.44 & 8.89 & 83.04 & 98.37 \\
\hline Botrytis fruit rot control with captan & 6.44 & 9.71 & 14.00 & 30.15 \\
\hline Tissue sample & 2.06 & 0.00 & 4.00 & 6.06 \\
\hline \multicolumn{5}{|l|}{ Inject fertilizer (potassium nitrate and calcium nitrate) ${ }^{x}$} \\
\hline (two applications) & 32.78 & 27.36 & 26.73 & 86.87 \\
\hline Evaporative cooling-overhead irrigation (three applications) & 24.60 & 22.83 & 0.00 & 47.43 \\
\hline \multicolumn{5}{|l|}{ Botrytis fruit rot control with fenhexamide and powdery mildew } \\
\hline Disassemble irrigation system & 49.50 & 1.03 & 0.00 & 50.53 \\
\hline Total harvest and postharvest costs per acre & 2551.68 & 182.12 & 794.59 & 3528.39 \\
\hline Total harvest and production costs per acre & 5358.73 & 1727.00 & 6469.96 & $13,555.69$ \\
\hline
\end{tabular}

${ }^{\mathrm{z}} \$ 1.00 /$ acre $=\$ 2.4711 / \mathrm{ha} ; \mathrm{l}$ acre $=0.4047 \mathrm{ha}$.

y Soybean (Glycine max), two-spotted spider mite (Tetranychus urticae), annual rye grass (lolium perenne), white-tail deer (Odocoileus virginiaus), clipper weevil (Anthonomus signatus), red fire ant (Solenopsis wagneri), honeybee (Apis mellifera).

${ }^{\mathrm{A}}$ Ammonium nitrate $=34 \mathrm{~N}-0 \mathrm{P}-0 \mathrm{~K}$, potassium sulfate $=0 \mathrm{~N}-0 \mathrm{P}-36.5 \mathrm{~K}-1 \mathrm{Mg}-18 \mathrm{~S}$, triple super phosphate $=0 \mathrm{~N}-22 \mathrm{P}-0 \mathrm{~K}-12 \mathrm{Ca}-1 \mathrm{~S}, \mathrm{Sul}-\mathrm{Po}-\mathrm{Mg}=0 \mathrm{~N}-0 \mathrm{P}-17.8 \mathrm{~K}-10.5 \mathrm{Mg}-21 \mathrm{~S}$, boron $=0 \mathrm{~N}-0 \mathrm{P}-0 \mathrm{~K}-20 \mathrm{~B}$, liquid nitrogen $=30 \mathrm{~N}-0 \mathrm{P}-0 \mathrm{~K}$, calcium nitrate $=15 \mathrm{~N}-0 \mathrm{P}-0 \mathrm{~K}-19 \mathrm{Ca}-1 \mathrm{Mg}$, potassium nitrate $=13 \mathrm{~N}-0 \mathrm{P}-35.5 \mathrm{~K}$

${ }^{\mathrm{w}}$ Botrytis fruit rot (Botrytis cinerea).

${ }^{v}$ Powdery mildew (Sphaerotheca macularis). 
Table 3. Estimated strawberry fumigation costs per acre for methyl bromide (MeBr) and selected alternative soil treatments and the fumigation costs of the alternative treatments compared to the fumigation costs associated with $\mathrm{MeBr}$.

\begin{tabular}{|c|c|c|c|c|c|}
\hline $\begin{array}{l}\mathrm{MeBr} \text { and selected } \\
\text { alternativesoil treatments }\end{array}$ & $\begin{array}{l}\text { Labor } \\
\text { costs }\end{array}$ & $\begin{array}{l}\text { Machinery } \\
\text { costs }\end{array}$ & $\begin{array}{l}\text { Materials } \\
\text { costs }\end{array}$ & $\begin{array}{c}\text { Total } \\
\text { fumigation costs }\end{array}$ & $\begin{array}{l}\text { Reduced fumigation } \\
\text { costs relative to } \mathrm{MeBr}\end{array}$ \\
\hline Metam sodium (shank) & 68.84 & 417.53 & 709.50 & 1195.87 & -71.03 \\
\hline Chloropicrin & 39.34 & 288.06 & 847.50 & 1174.90 & -92.00 \\
\hline Telone-C35 & 39.34 & 288.06 & 779.50 & 1106.90 & -160.00 \\
\hline Telone II & 39.34 & 288.06 & 660.50 & 987.90 & -279.00 \\
\hline Metam sodium (drip) & 0.00 & 6.72 & 897.00 & 903.72 & -363.18 \\
\hline Nonfumigated & 39.34 & 288.06 & 439.50 & 766.90 & -500.00 \\
\hline
\end{tabular}

${ }^{{ }^{2} 1.00 / \text { acre }=\$ 2.4711 / \text { ha. }}$

Table 4. The average number of strawberry planting holes with weeds, the estimated time required to pull the weeds, the estimated weeding cost per acre for methyl bromide $(\mathrm{MeBr})$ and selected alternative soil treatments, and the difference in the weeding costs relative to MeBr based on fumigation trials in Plymouth, N.C.

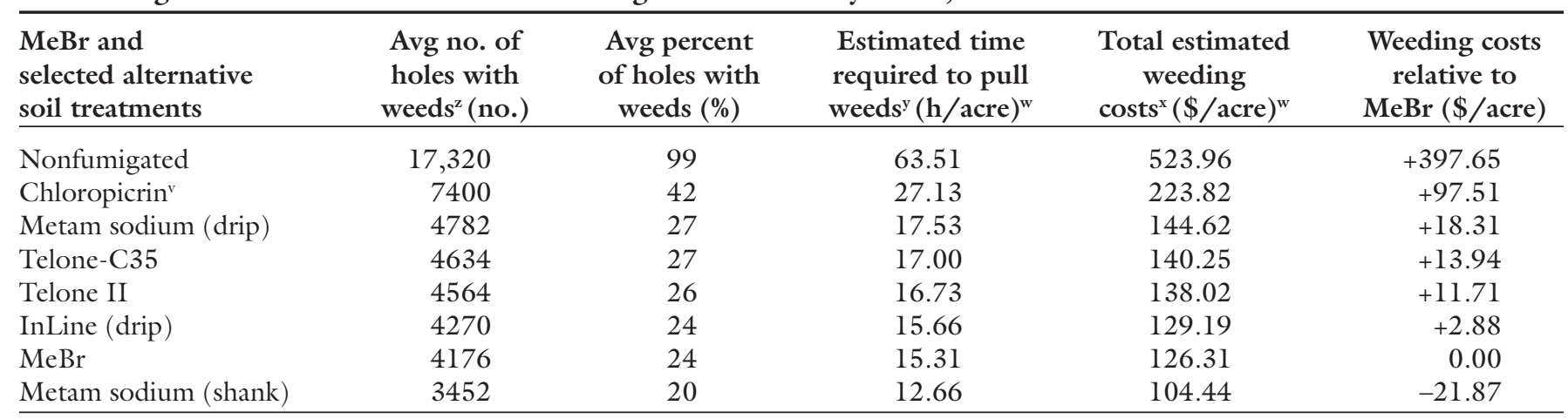

${ }^{2}$ Based on mean number of weeds per plot, counts taken in Feb. 2000, 2001, and 2003, assuming 17,400 holes/acre (42,996 holes/ha).

yCalculated assuming time for removal of weeds is $11 \mathrm{~s} /$ hole, based on random samples taken during weeding throughout the experiments. The time given was calculated as actual weeding time multiplied by 1.2 to capture additional time spent on the operation associated with preparation, rest, etc.

Calculated based on a wage rate of $\$ 8.25 / \mathrm{h}$.

w $1 \mathrm{~h} /$ acre $=2.4711 \mathrm{~h} \cdot \mathrm{ha}^{-1} ; \$ 1.00 /$ acre $=\$ 2.4711 / \mathrm{ha}$

"Weed pressure with TriClor alternative was assumed to be the same as with chloropicrin.

Table 5. Average marketable strawberry yields for the years and locations the trials were conducted, the harvest-related costs per acre, including labor and materials, and gross returns for methyl bromide ( $\mathrm{MeBr}$ ) and selected alternative soil treatments and the difference in the harvest costs and yield values relative to $\mathrm{MeBr}$ for the piedmont and coastal plain area.

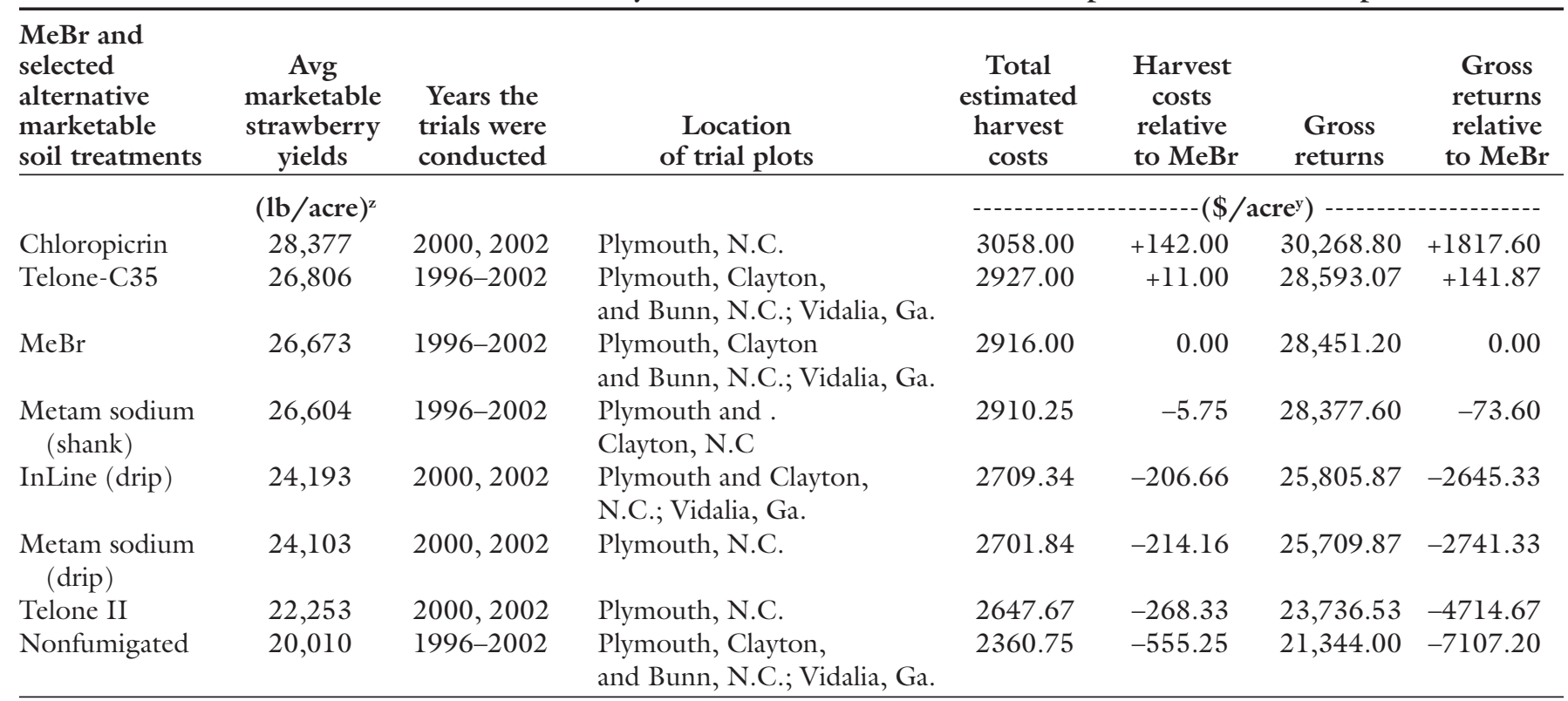


Table 6. Average marketable strawberry yields for the years and locations the trials were conducted, the harvest-related costs per acre, including labor and materials, and gross returns for methyl bromide ( $\mathrm{MeBr})$ and selected alternative soil treatments and the difference in the harvest costs and yield values relative to $\mathrm{MeBr}$ for the mountain area.

\begin{tabular}{|c|c|c|c|c|c|c|c|c|c|c|c|c|}
\hline $\begin{array}{l}\text { MeBr and } \\
\text { selected } \\
\text { alternative } \\
\text { marketable } \\
\text { soil treatments }\end{array}$ & $\begin{array}{r}A \\
\text { mark } \\
\text { strav } \\
\text { yi }\end{array}$ & $\begin{array}{l}\text { table } \\
\text { erry } \\
\text { ds }\end{array}$ & $\begin{array}{l}\text { Years } \\
\text { trials } \mathrm{y} \\
\text { conduc }\end{array}$ & & & $\begin{array}{l}\text { Location } \\
\text { of trial plots }\end{array}$ & & $\begin{array}{r}\text { Tota } \\
\text { estima } \\
\text { harve } \\
\text { cost }\end{array}$ & $\begin{array}{l}\text { Harv } \\
\text { cost } \\
\text { relati } \\
\text { to } \mathrm{Mc}\end{array}$ & & $\begin{array}{l}\text { Gross } \\
\text { returns }\end{array}$ & $\begin{array}{l}\text { Gross } \\
\text { returns } \\
\text { relative } \\
\text { to } \mathrm{MeBr}\end{array}$ \\
\hline & $(\mathrm{lb})$ & $(\mathrm{cre})^{\mathrm{z}}$ & & & & & & & $-\cdots$ & $1 \%$ & $\left.\operatorname{ccre}^{y}\right)$ & - \\
\hline InLine (drip) & 12 & & 2001,2 & & Leices & ster, N.C. & & 1713. & +94.5 & & $13,050.67$ & +1209.60 \\
\hline $\mathrm{MeBr}$ & 11 & & 1997-2 & & Fletch & her and Leicester, 1 & N.C. & 1618. & 0.0 & & $11,841.07$ & 0.00 \\
\hline Nonfumigated & 11 & & 1997-9 & & Fletch & her and Leicester, 1 & N.C. & 1611. & -6.6 & & $11,755.73$ & -85.34 \\
\hline $\begin{array}{l}\text { Metam sodium } \\
\quad(\text { drip })\end{array}$ & 10 & & 2001,2 & 02 & Leices & ster, N.C. & & 1592. & -25.8 & & $11,510.40$ & -330.67 \\
\hline $\begin{array}{l}\mathrm{z} 1 \mathrm{lb} / \mathrm{acre}=1.1209 \\
\mathrm{y} \$ 1.00 / \mathrm{acre}=\$ 2.47\end{array}$ & & & & & & & & & & & & \\
\hline $\begin{array}{l}\mathrm{MeBr} \\
\text { and selected } \\
\text { alternative soil } \\
\text { treatments }\end{array}$ & & $\begin{array}{r}\text { Adde } \\
\text { of } \\
\text { alter } \\
\text { trea }\end{array}$ & $\begin{array}{l}d \text { costs } \\
\text { the } \\
\text { native } \\
\text { tment }\end{array}$ & $\begin{array}{r}\mathrm{Re} \\
\mathrm{re} \\
\mathrm{O} \\
\text { alte } \\
\text { trea }\end{array}$ & $\begin{array}{l}\text { uced } \\
\text { urns } \\
\text { the } \\
\text { native } \\
\text { ment }\end{array}$ & $\begin{array}{c}\text { Total } \\
\text { negative effects } \\
\text { of the } \\
\text { alternative } \\
\text { treatment }\end{array}$ & $\begin{array}{r}\text { Red } \\
\mathrm{cc} \\
\text { of } \\
\text { alter } \\
\text { trea }\end{array}$ & $\begin{array}{l}\text { uced } \\
\text { sts } \\
\text { the } \\
\text { native } \\
\text { ment }\end{array}$ & $\begin{array}{l}\text { Added } \\
\text { returns } \\
\text { of the } \\
\text { alternative } \\
\text { treatment }\end{array}$ & $\begin{array}{r}\text { pos } \\
\mathbf{a} \\
\mathbf{t}\end{array}$ & $\begin{array}{l}\text { Total } \\
\text { itive effects } \\
\text { of the } \\
\text { lternative } \\
\text { reatment }\end{array}$ & $\begin{array}{c}\text { Additional } \\
\text { net returns } \\
\text { of the } \\
\text { alternative } \\
\text { treatment }\end{array}$ \\
\hline Chloropicrin & & & 9.51 & & .00 & 239.51 & & .00 & 1817.60 & & 1909.60 & +1670.09 \\
\hline Telone-C35 & & & 5.03 & & .00 & 25.03 & 160 & .00 & 141.87 & & 301.87 & +276.84 \\
\hline Metam sodium & ank) & & 0.00 & & 3.60 & 73.60 & & .66 & 0.00 & & 98.66 & +25.06 \\
\hline
\end{tabular}

${ }^{\mathrm{z}} \$ 1.00 /$ acre $=\$ 2.4711 / \mathrm{ha}$.

Table 8. The total negative effects, added costs and reduced returns, the total positive effects, reduced costs and added returns, and the additional net returns incurred by substituting the selected alternative soil treatment for methyl bromide $(\mathrm{MeBr})$ in the strawberry production in the mountain area.

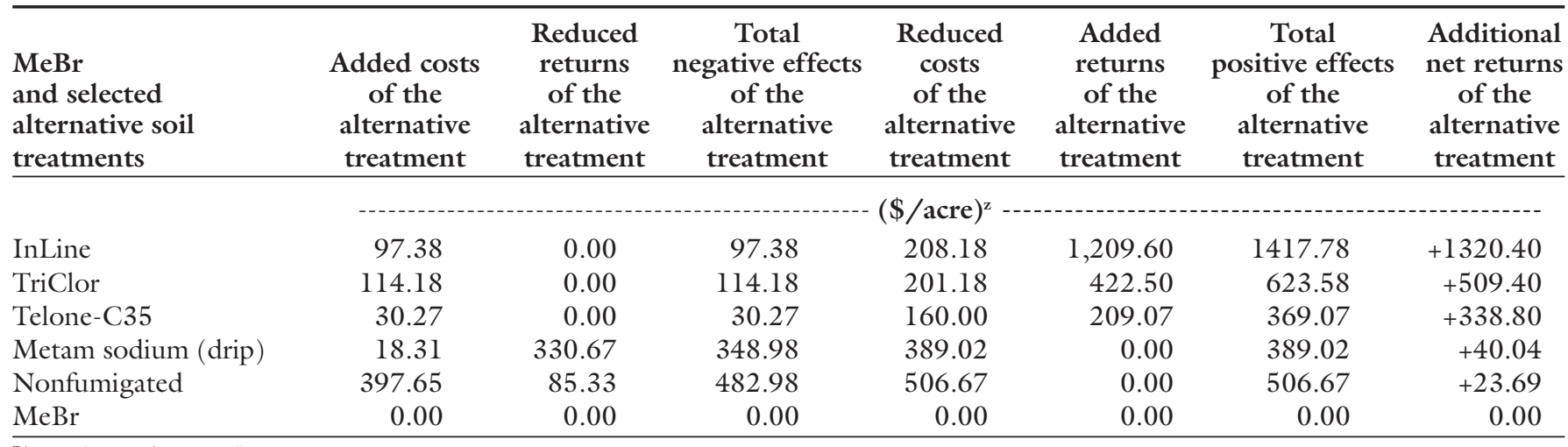

${ }^{\mathrm{z}} \$ 1.00 /$ acre $=\$ 2.4711 / \mathrm{ha}$. 
Table 9. Estimated gross returns, costs incurred to fumigate, weed, harvest, produce, and market strawberries, total net returns for each soil treatment and the additional net returns per acre of the selected alternative soil treatments relative to methyl bromide $(\mathrm{MeBr})$ for the piedmont and coastal plain area.

\begin{tabular}{|c|c|c|c|c|c|c|c|}
\hline $\begin{array}{l}\text { MeBr } \\
\text { and selected } \\
\text { alternative soil } \\
\text { treatments }\end{array}$ & $\begin{array}{l}\text { Gross } \\
\text { returns }\end{array}$ & $\begin{array}{c}\text { Fumigation } \\
\text { costs }\end{array}$ & $\begin{array}{l}\text { Weeding } \\
\text { costs }\end{array}$ & $\begin{array}{l}\text { Harvest } \\
\text { costs }\end{array}$ & $\begin{array}{c}\text { Other } \\
\text { production and } \\
\text { marketing } \\
\text { costs }^{\mathrm{z}}\end{array}$ & $\begin{array}{l}\text { Total } \\
\text { net } \\
\text { returns }\end{array}$ & $\begin{array}{c}\text { Additional } \\
\text { net returns } \\
\text { relative to } \\
\mathrm{MeBr}\end{array}$ \\
\hline Chloropicrin & $30,268.80$ & 1174.90 & 223.82 & 3058.00 & 9246.48 & $16,565.60$ & +1670.09 \\
\hline Telone-C35 & $28,593.07$ & 1106.90 & 140.25 & 2927.00 & 9246.48 & $15,172.44$ & +276.93 \\
\hline Metam sodium (drip) & $25,709.87$ & 903.72 & 144.62 & 2701.84 & 9246.48 & $12,713.21$ & -2182.30 \\
\hline InLine (drip) & $25,805.87$ & 1058.72 & 129.19 & 2709.34 & 9246.48 & $12,662.14$ & -2233.37 \\
\hline Telone II & $23,736.53$ & 987.90 & 138.02 & 2647.67 & 9246.48 & $10,716.46$ & -4179.05 \\
\hline Nonfumigated & $21,344.00$ & 766.90 & 523.96 & 2360.75 & 9246.48 & 8845.91 & -6449.60 \\
\hline
\end{tabular}

${ }^{2}$ The production and marketing costs that did not change as a result of varying the soil treatments.

Excluding land rental rates.

${ }^{\mathrm{x}} \$ 1.00 /$ acre $=\$ 2.4711 / \mathrm{ha}$

Table 10. Estimated gross returns, costs incurred to fumigate, weed, harvest, produce and market strawberries, total net returns for each soil treatment and the additional net returns per acre of the selected alternative soil treatments relative to methyl bromide $(\mathrm{MeBr})$ for the mountain area.

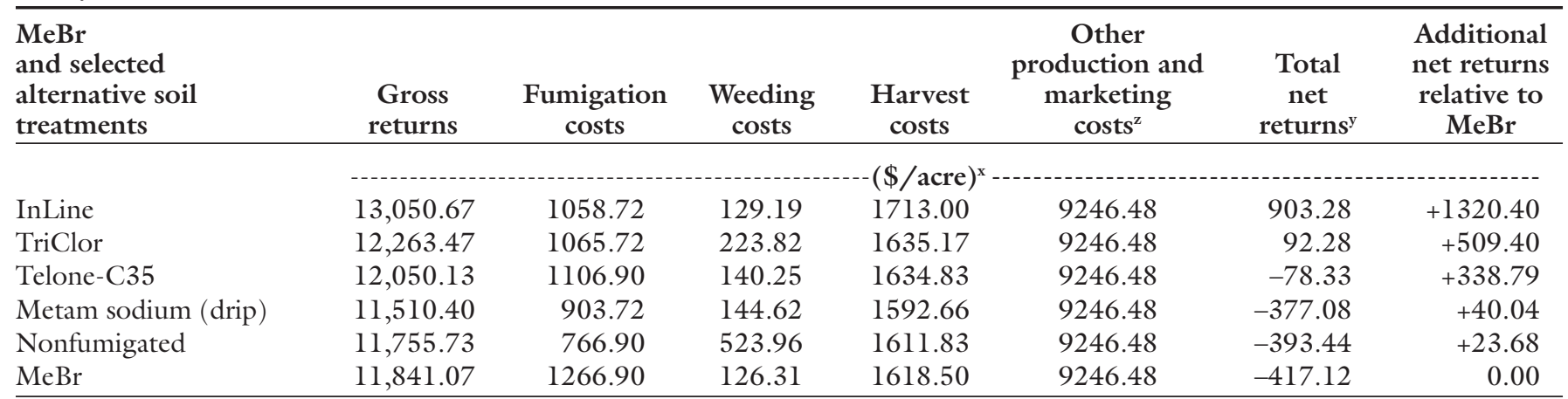

${ }^{2}$ The production and marketing costs that did not change as a result of varying the soil treatments.

yxcluding land rental rates.

${ }^{\mathrm{x}} \$ 1.00 / \mathrm{acre}=\$ 2.4711 / \mathrm{ha}$

are summarized in Table 9 for the piedmont and coastal plain area and in Table 10 for the mountain area.

In the piedmont and coastal plain area (Table 7), fumigation with chloropicrin was the most cost effective, resulting in an additional return of $\$ 1670$ /acre relative to $\mathrm{MeBr}$. TeloneC35 also brought about a positive return of $\$ 277 /$ acre, while the estimated return for shank-applied metam sodium was approximately equal to the return associated with $\mathrm{MeBr}$ (an additional return $\$ 25 /$ acre). Other soil treatment alternatives resulted in reduced returns relative to $\mathrm{MeBr}$. The estimated return for metam sodium (drip) and InLine were similar, with projected losses of $\$ 2182$ /acre and $\$ 2233 /$ acre relative to $\mathrm{MeBr}$, and Telone II had an estimated loss of $\$ 4179 /$ acre. As expected, the projected return for the nonfumigated soil treatment resulted in the largest loss return relative to $\mathrm{MeBr}$ (\$6450/acre).

In the mountain area (Table 8 ), all of the alternatives resulted in an increase in the projected returns compared to $\mathrm{MeBr}$. The highest increase in returns was estimated for the InLine treatment $(\$ 1320 /$ acre $)$, while additional returns were more modest for TriClor $(\$ 509 /$ acre $)$ and Telone C-35 (\$339/acre). Projected returns for the metam sodium (drip) and nonfumigated treatments were very similar to the $\mathrm{MeBr}$ treatment with increases of $\$ 40 /$ acre and $\$ 24 /$ acre, respectively.

The estimated net returns for $\mathrm{MeBr}$ and the alternative soil treatments are presented in Tables 9 and 10 . The net return for each soil treatment is the difference between the projected gross returns and the associated costs that changed as a result of applying different soil treatments plus the remain- ing production and marketing costs that remained constant regardless of the soil treatment used. For example, in the piedmont and coastal plain area, the projected gross returns for the $\mathrm{MeBr}$ alternative were $\$ 28,451.20$ / acre (Table 5), while the associated fumigation costs were $\$ 1266.90 /$ acre (Table 3 ), the weeding costs were 126.31/acre (Table 4), and the harvest costs were $\$ 2916.00 /$ acre (Table 5). Therefore the production and marketing costs that did not change as a result of varying the soil treatments were $\$ 9246.48 /$ acre, which was calculated by subtracting the fumigation, weeding, and harvest costs from the total production costs of $\$ 13,555.69 /$ acre (Table 2). This procedure yielded an estimated net return, less a land rental rate, of $\$ 14,895.51$ /acre for the $\mathrm{MeBr}$ treatment. The net returns for the other soil treatment alternatives were calculated the same way. 
The net returns were much higher in the piedmont and coastal plain area (Table 9) compared to the mountain area (Table 10) because of the significant difference in average marketable yields. In the piedmont and coastal plain area, fumigating with chloropicrin produced the highest projected net return $(\$ 16,566 /$ acre $)$, followed by Telone-C35 (\$15,172/acre), shankapplied metam sodium $(\$ 14,921 /$ acre), drip-applied metam sodium (\$12,713/acre), InLine (\$12,662/ acre), and Telone II ( $\$ 10,716 /$ acre $)$. The nonfumigated soil treatment resulted in the lowest net return estimate (\$8846/acre).

In the mountain area, the InLine treatment had the highest projected net return $(\$ 903 /$ acre $)$ and the TriClor treatment had an estimated net return of $\$ 92$ /acre. However, the remaining soil treatments, including $\mathrm{MeBr}$, showed projected losses because the low yields did not generate enough gross revenues to cover the production costs.

\section{Conclusions}

This paper contributes to the literature exploring the feasibility of $\mathrm{MeBr}$ alternatives used in the production of strawberries. This economic analysis explored the cost-effectiveness of the alternative soil treatments and their impact on net revenues using the partial budget methodology. Results indicate that there are economically feasible fumigation alternatives to $\mathrm{MeBr}$ in the production of strawberries in the southeastern U.S. However, the performance of the alternatives is not uniform throughout the region. Chloropicrin shows good potential for growing conditions similar to those of the piedmont and coastal plain area, with additional returns of $\$ 1670 /$ acre relative to $\mathrm{MeBr}$. More modest improvements were projected for TeloneC35 and shank-applied metam sodium with additional returns of $\$ 277 /$ acre and $\$ 25 /$ acre, respectively. For growing conditions similar to those in the mountains of North Carolina, all of the alternatives showed an improvement in the projected net returns relative to $\mathrm{MeBr}$. Fumigation with InLine showed the greatest potential with an additional return of $\$ 1320 /$ acre relative to $\mathrm{MeBr}$.

Even though this analysis showed a negative return in the mountains using $\mathrm{MeBr}$ in the plasticulture sys- tem, some growers find it profitable to produce strawberries. This budget should serve as a tool for growers to calculate the potential return on their investment and time based on a customized budget for their location and growing conditions. This study also highlights that growers should give careful consideration to their input costs and their fumigation options. Additional trials, particularly on-farm trials where growers practice beneficial crop rotation and cover crop practices, will help growers determine if fumigation is a necessary expense for their production system.

For the purposes of this analysis, all data were included, despite technical or environmental issues encountered. For example, the InLine treatments at the Plymouth, N.C., site in the 2001-02 production year failed to offer an advantage compared to the nonfumigated plot. This particular batch of product also failed at other experimental sites, suggesting that there was a problem with the formulation. However, it was not clear if the formulation was ineffective or if there were other undetermined issues. The experiments were designed to avoid problems associated with improper application or sub-optimal soil conditions. Values for all the years were included in this analysis, potentially representing a level of risk associated with the alternative. InLine performed best in the mountain production region and thus offers considerable promise as an economically viable alternative, and the economic returns a grower may expect with the InLine alternative in the piedmont and coastal plain area could be underestimated. Likewise, slight phytotoxicity was associated with the Telone-C35 treated plots in Plymouth in the 1998-99 and 1999-2000 experiments. This appeared to have been associated with water-saturated soils after the treatments were applied due to hurricane and heavy rain events, even with a plant-back time of over 21 d. Despite depressed yields in these data points, across years and sites, Telone-C35 offered a higher return than $\mathrm{MeBr}$. Thus, a grower may expect higher returns on average if phytoxicity is not encountered. Alternatively, plant-back issues and the potential for phytotoxicity, particularly in wet autumns, highlight technical issues currently associated with some of the alternatives.
In general, weed pressure was low at Plymouth. Although weed data were not collected in all locations, relative impacts of soil treatment would be similar; that is, no fumigation will always result in highest weed counts, while some fumigants are known to be less effective in controlling weeds. In the future, growers may need to vary their protocol to include additional herbicide treatments to reduce weed pressure if $\mathrm{MeBr}$ is not used.

These results are based on a study in progress. The availability of the updated information on yield estimates associated with possible fumigation alternatives may affect the above conclusions. Additionally, the availability of the cost information for iodomethane and analysis of its performance may add another feasible alternative. The audience of this article should also be aware that the results represent estimates only and are not a guarantee, since the performance of the fumigation alternatives investigated here varied in different locations based on particular local conditions.

\section{Literature cited}

Abad, Z.G., F.J. Louws, and G.E. Fernandez. 1999. Rhizoctonia and Pythium species associated with black root rot of strawberries in North Carolina. Phytopathology 89:S1. (Abstr.)

Abad, Z.G., F.J. Louws, G.E. Fernandez, and L.M. Ferguson. 2002. Predominance and pathogenicity of fungi and stramenopiles associated with black root rot of strawberries. Phytopathology 92S1. (Abstr.)

Brannen, P.M., L.M. Ferguson, and F.J. Louws. 2003. Alternatives to methyl bromide use for control of black rot of strawberry in Georgia, 2002. Fungicide Nematicide Tests 58:SMF020.

Brannen, P.M. and F.J. Louws. 2002 . Alternatives to methyl bromide use for control of black rot of strawberry in Georgia, 2001. Fungicide Nematicide Tests 57:SMF47.

Carpenter, J., L.Gianessi, and L.Lynch. 2000. The economic impact of the scheduled U.S. phaseout of methyl bromide. Natl. Ctr. for Food and Agr. Policy. 14 Oct. 2005. <http://www.ncfap.org/reports/ pesticides /methy $\% 20$ bromide/methylbromide.htm

Carter, C.A., J.A. Chalfant, R.E. Goodhue, and G.J. McKee. 2005. Costs of 2001 methyl bromide rules estimated for California strawberry industry. California Agr. 59:41-46. 
Dalsted, N.L. and P.H. Gutierrez. 1992. Partial budgeting. Colorado State Univ. Coop. Ext. Rpt. No. 3.760.

Driver, J.G., L.M. Ferguson, F.J. Louws, G.E. Fernandez, P.M. Brannen, and E.B. Poling. 2001. Drip vs. shank application of chemical alternatives to methyl bromide. Proc. Intl. Res. Conf. on Methyl Bromide Alternatives and Emissions Reduction 87/1-87/2. 14 Oct. 2005. <http://www.mbao.org/200lproc/ 087\%20Driver\%20JG\%20dripvsshank01. pdf>.

Duniway, J.M. 2002. Status of chemical alternatives to methyl bromide for preplant fumigation of soil. Phytopathology 92:1337-1343.

Ferguson, L.M., G.E. Fernandez, P.M. Brannen, F.J. Louws, E.B. Poling, O. Sydorovych, C.D. Safley, D.W. Monks, Z. Pesic-Van Esbroeck, D.C. Sanders, and J.P. Smith. 2001. Alternative soil treatments for strawberry in the southeastern United States. Proc. Intl. Res. Conf. on Methyl Bromide Alternatives and Emissions Reduction 42/1-42/4. 14 Oct. 2005. <http://www.mbao.org/2001 proc/ 042\%20Ferguson\%20LM\%mbaoconfA01. pdf>.

Ferguson, L.M., F.J. Louws, Z.G. Abad, G. E. Fernandez, E.B. Poling, and P.M. Brannen. 2003. Impacts of alternatives on strawberry yield and root colonization by fungal pathogens. Proc. Intl. Res. Conf. on Methyl Bromide Alternatives and Emissions Reduction 56/1-56/8. 14 Oct. 2005. <http://www.mbao.org/2003/ 056\%LouwsFFergusonetal2003.pdf>.

Ferguson, L.M., F.J. Louws, G.E. Fernandez, P.M. Brannen, E.B. Poling, O. Sydorovych, C.D. Safley, D.W. Monks, A. Pesic-Van Esbroeck, D.C. Sanders, and J.P. Smith. 2002. Chemical and biological alternatives to methyl bromide for strawberry in the southeastern U.S. Proc. Intl. Res. Conf. on Methyl Bromide Alternatives and Emissions Reduction. <http://www. mbao/org/2002proc/103/1-103/4. 14 Oct. 2005. 103LouwsF\%20AMBAOstraw berryabstrll.pdf>.

Fernandez, G.E., Z.G. Abad, and F.J. Louws. 2000. Chemical alternatives to methyl bromide for strawberry production in North Carolina. Proc. Intl. Res. Conf. on Methyl Bromide Alternatives and Emissions Reduction 35/1-35/2. 14 Oct. 2005. <http://www.mbao.org/ altmet00/35louws.pdf $>$.
Gullino, M.L., A. Camponogara, G. Gasparrini, V. Rizzo, C. Clini, and A. Garibaldi. 2003. Replacing methyl bromide for soil disinfestation: The Italian experience and implications for other countries. Plant Dis. 87:1012-1021.

Kay, R.D. and W.M. Edwards. 1994. Farm management. McGraw-Hill, New York.

Louws, F.J., G.E. Fernandez, and M. Grabowski. 1998a. Compost as an alternative to methyl bromide and as a means for nutrient management for strawberry production. Proc. Intl. Res. Conf. on Methyl Bromide Alternatives and Emissions Reduction 21/1-21/2. 14 Oct. 2005. <http:www.mbao.org/1998airc/ 021louws.pdf>.

Louws, F.J., G.E. Fernandez, G. Miner, D. Monks, E. Bish, B. Poling, and K. Sorensen. 1998b. Methyl bromide alternatives research for strawberry production in North Carolina. Proc. Intl. Res. Conf. on Methyl Bromide Alternatives and Emissions Reduction 22/1-22/2. 14 Oct. 2005. <http://www.mbao. org/1998airc/022sorenson.pdf>.

Louws, F.J., M.A. Grabowski, G.E. Fernandez, and J.B. Vollmer. 2000. Compost as an alternative to methyl bromide in plasticulture strawberry production. Proc. Intl. Res. Conf. Methyl Bromide Alternatives and Emissions Reduction 33/1-33/2. 14 Oct. 2005 <http://www.mbao.org/ altmet00/33louws.pdf $>$.

Manning, G.R. and S.A. Fennimore. 2001. Evaluation of low-rate herbicides to supplement methyl bromide alternative fumigants to control weeds in strawberry. HortTechnology 11(4):603-609.

Martin, F.N. 2003. Development of alternative strategies for management of soil borne pathogens currently controlled with methyl bromide. Annu. Rev. Phytopathol. 41:325-350.

Norman, C.S. 2005. Potential impacts of imposing methyl bromide phase out on US strawberry growers: A case study of a nomination for a critical use exemption under the Montreal Protocol. J. Environ. Mgt. 75:167-176.

Osteen, C. 2000. Economic implications of the methyl bromide phaseout. U.S. Dept. Agr., Econ. Res. Serv. USDA-ERS Agr. Info. Bul. 756.
Rieger, M., G. Krewer, and P. Lewis. 2001. Solarization and chemical alternatives to methyl bromide for preplant soil treatment of strawberries. HortTechnology $11(2): 258-264$.

Ristaino, J.B. and Thomas, W. 1997. Agriculture, methyl bromide, and the ozone hole: Can we fill the gaps? Plant Dis. 81:964-977.

Roberts, W.S. and S.M. Swinton. 1996. Economic methods for comparing alternative crop production systems: A review of the literature. Amer. J. Alternative Agr. 11(1):10-17.

Safley, C.D., E.B. Poling, M.K. Wohlgenant, O. Sydorovych, and R.S. Williams. 2004. Producing and marketing strawberries for direct market operations. HortTechnology 14(1):16-27.

Schneider, S.M., E.N. Rosskopf, J.G. Leesch, D.O. Chellemi, C.T. Bull, and M. Mazzola. 2003. USDA, ARS research on alternatives to methyl bromide: Preplant and post-harvest. Pest Mgt. Sci. 59:814-826.

U.S. Department of Agriculture. 2001. Integrated methyl bromide transition strategies in the southeastern United States. Coop. State Res., Educ., Ext. Serv. NonTech. Prog. Rpt.

U.S. Department of Agriculture. 2005a. ARS methyl bromide research. USDA, Agr. Res. Serv., 14Oct. 2005 <http://www.ars. usda.gov/is $/ \mathrm{mb} /$ mebrweb.htm>.

U.S. Department of Agriculture. 2005b. Methyl bromide phaseout proceeds: Users request exemptions. USDA, Econ. Res. Serv., 14 Oct. 2005 <http://www. ers.usda.gov/Amberwaves/April03/Features/MethylBromide.htm>.

U.S. Environmental Protection Agency. 2004. Protection of stratospheric ozone: Process for exempting critical uses from the phaseout of methyl bromide; final rule. 14 Oct. 2005 <http:www.epa/gov/ozone/ mbr/CUEFinalRuleFedReg.pdf>.

Warmann, G.W. 1995. Economics of liming Kansas cropland: Owner-operator and landlord-tenant considerations. Kansas State Univ. Agr. Expt. Sta. and Coop. Ext. Serv. Publ. MF-2137.

Wossink, G.A.A. and D.L. Osmond. 2002. Farm economics to support the design and selection of cost-effective BMPs: Nitrogen control in the Neuse River Basin, North Carolina. J. Soil Water Conservation 57(4):213-220. 